\title{
Increased DNA Damage, Instability and Cytokinesis Defects in Occupationally Exposed Car Painters
}

\author{
ANTONIO PEDRO DOS REIS FILHO, MARUHEN AMIR DATSCH SILVEIRA, \\ NATANI RIBEIRO DEMARCO and LUCIANA PAULA GREGIO D'ARCE \\ Centro de Ciências Biológicas e da Saúde, Colegiado de Ciências Biológicas, \\ State University of Western Paraná, Parana, Brazil
}

\begin{abstract}
Background/Aim: Car painting is considered an occupational exposure job with high risk for cancer development, due to the association with harmful chemicals and mutagens. This study aimed to profile car painters occupationally exposed and determine its association with DNA damage and genomic instability. Materials and Methods: We collected a questionnaire and buccal cells of 74 individuals (37 car painters and 37 non-exposed workers) paired by age, alcohol and smoking habits. The number of pyknotic cells, karyolitic cells, karyorrhetic cells, condensed chromatin, binucleated cells, basal cells, differentiated cells (DIFF), micronucleated cells and nuclear buds were evaluated using the Buccal Micronucleus Cytome Assay protocol. Results: A statistically significant increase was observed in all parameters $(p<0.05)$ in the exposed group, but DIFF showed a statistically significant decrease $(p<0.001)$, compared to the control group. Conclusion: In association with the poor work environment and lack of personal and collective protective equipment, occupational exposure of car painters leads to high DNA damage, genomic instability and alterations in cellular kinetics.
\end{abstract}

Human biomonitoring studies have tried to establish an association between the risk for future diseases and occupational exposure, life style and environmental and nutritional contamination (1-11). In this context, car painting represents a potential occupational hazard, especially due to the known use of benzene, isocyanates, toluene and xylene

This article is freely accessible online.

Correspondence to: Maruhen Amir Datsch Silveira, Universidade Estadual do Oeste do Paraná, Rua Universitária, 2069, Jardim Universitário, Cascavel - PR, CEP: 85819-110, Brazil. Tel: +55 4532203235, e-mail: maruhensilveira@gmail.com

Key Words: Buccal micronucleus cytome assay, cellular kinetics, DNA instability, cancer risk, occupational exposure mutagenesis.
(12, 13). The International Agency for Research on Cancer (IARC) already classified commercial painting as a high-risk group for lung and bladder cancer development (14), whereas the major pathways of exposure involve inhalation of vapors and gases, dermal absorption and/or ingestion (15). While, benzene is already classified by IARC as "carcinogenic to humans", isocyanates, toluene and xylene per se are classified as "not classified as to their carcinogenicity in humans", even with the crescent literature associating painters with chemical contamination and diseases $(16,17)$. Another major issue is that some workers do not even know about these classifications, so they tend to ignore personal and collective protective equipment, what could increase the risk for future diseases.

Given the association between car painting and the potential and proven harmful mutagens and carcinogens, this study aimed to profile individuals working as car painters for at least 8 years. We selected the Buccal Micronucleus Cytome assay (BMCyt) (1), as a reliable and cost-effective test to evaluate cellular biomarkers of early toxicity effects. BMCyt was selected since the different cellular types can be easily observed in buccal samples and may be categorized according to DNA damage level, genomic (in) stability and cellular kinetics, providing a full spectrum for a genetic screening using a minimally invasive test.

Here, we matched by age, alcohol and smoking habits 37 car painter workers (exposed group) for at least 8 years with 37 non-exposed individuals. Due to availability, only men were included in this study. Our groups included only individuals with no familial history of cancer or any chronic diseases. The BMCyt test was performed and statistically significant differences were observed in the exposed group in all cellular parameters evaluated $(p<0.05)$, indicating high DNA damage, genome instability and alterations in cellular kinetics, arguing for occupational exposition. Furthermore, most of car painters declared no use of personal protective equipment, what likely corroborate the results. All in all, our study demonstrated the feasibility of performing the BMCyt test to identify early biomarkers for occupational exposition in car painters and 
Table I. Demographic characteristics of the studied population.

\begin{tabular}{|c|c|c|c|c|c|c|c|}
\hline & \multirow[b]{2}{*}{$\mathrm{N}$} & \multirow[b]{2}{*}{ Age (years) } & \multicolumn{2}{|c|}{ Smoking } & \multicolumn{3}{|c|}{ Alcohol consumption } \\
\hline & & & Smokers & Non-smokers & Non consumer & Moderate consumers & High Consumers \\
\hline EXP & 37 & 43.2 & 15 & 22 & 6 & 25 & 6 \\
\hline $\mathrm{CON}$ & 37 & 42.5 & 15 & 22 & 6 & 25 & 6 \\
\hline
\end{tabular}

EXP: Exposed group; CON: control group; Age in years calculated as average; NC: non-consumer; MC: moderate consumer; HC: high consumer.

represents an important stepforward to suggest genetic screenings to determine future disease risk, including cancer.

\section{Materials and Methods}

Acquisition of sample data. All individuals signed an Informed Consent approved by an Ethics Committee (CAAE: 65453117.4.0000.0107) and completed a questionnaire. The car painters group consisted of 37 workers (exposed group), paired by gender, age, smoking and alcoholic habits with 37 non-exposed individuals (control group). Individuals from our study were born in the same state in Brazil. The exposed group consisted of individuals working as car painters for at least 8 years. Non-exposed individuals included individuals working in no known occupational exposure jobs and without known chemical exposure at home. All individuals filled out a questionnaire to provide identification, family history, smoking habits, alcohol consumption and medical history. Two major groups were created and we were carefull to include only individuals without family history of cancer or any chronic disease. Cigarette smokers were defined as those who had smoked at least 100 cigarettes during their lifetime, or were at the time of recruitment smoking occasionally or every day; ex-smokers were classified as those who had stopped smoking for at least one year prior to collection (18). To evaluate alcohol consumption, individuals were classified as in Silveira et al. (8): non-consumer, defined as any alcohol consumption or social consumption; moderate consumer, defined as consuming up to 1 cup (about $100 \mathrm{ml}$ ) of alcohol per day, or more than a glass on weekends; high consumer, defined as the consumption of more than 11 of light alcoholic beverage (beer, wine or cider), or 2 glasses of spirits (rum, vodka, or whiskey) per day, for at least 6 years. Table I shows the demographic data of the studied population.

Workplace conditions. Car painters usually works indoor, for at least $40 \mathrm{~h}$ per week. Most of the workers $(90 \%)$ declared no use of personal protective equipment and that their work environment was not equipped with basic collective protective equipments as working cabins and air extractors.

Buccal micronucleus cytome assay (BMCyt). Both groups (exposed and control) were submitted to the same procedure for sample collection and preparation. Collection of the oral mucosa and the preparation of slides were performed according to the protocol described by Thomas et al. (1), with slight modifications already published by Silveira et al. (8) and Filho et al. (4). Briefly, buccal mucosa cells were collected by scraping the inner cheek using a sterille swab and placed in $3 \mathrm{ml}$ of saline solution. Samples were centrifuged at $1000 \mathrm{rpm}$ for $10 \mathrm{~min}$ and fixed using glacial acetic
Table II. Mean and standard error of the results comparing the exposed group to the control group using 1000 cells or $^{\prime} 2000$ cells ${ }^{\# \# . ~}$

\begin{tabular}{lccc}
\hline Biomarkers & $\begin{array}{c}\text { Exposed group } \\
(\mathrm{n}=37)\end{array}$ & $\begin{array}{c}\text { Control group } \\
(\mathrm{n}=37)\end{array}$ & $p$-Value \\
\hline Basal cells $^{\#}$ & $92.13 \pm 30.00^{*}$ & $66.35 \pm 25.32$ & $\leq 0.001$ \\
Differentiated cells $^{\#}$ & $832.84 \pm 40.42^{*}$ & $895.18 \pm 42.89$ & $\leq 0.001$ \\
Condensed Chromatin $^{\#}$ & $27.39 \pm 13.08^{*}$ & $11.40 \pm 4.95$ & $\leq 0.001$ \\
Binucleated cells $^{\#}$ & $13.52 \pm 5.36^{*}$ & $7.81 \pm 3.85$ & $\leq 0.001$ \\
Karyolitic\# $^{\#}$ & $13.86 \pm 5.69^{*}$ & $5.51 \pm 3.49$ & $\leq 0.001$ \\
Pyknotic $^{\text {Karyorrhetic\# }}$ & $10.50 \pm 5.48^{*}$ & $5.37 \pm 2.25$ & $\leq 0.001$ \\
Micronuclei\#\# $_{\text {Nuclear Buds }}^{\# \#}$ & $7.44 \pm 4.57^{*}$ & $4.89 \pm 2.92$ & $\leq 0.05$ \\
& $12.57 \pm 3.43^{*}$ & $3.70 \pm 2.14$ & $\leq 0.001$ \\
& $13.13 \pm 5.00^{*}$ & $4.91 \pm 2.95$ & $\leq 0.001$ \\
\hline
\end{tabular}

$t$-test used for statistics. ${ }^{*} p<0.05$.

acid and methanol $(1: 3, \mathrm{v} / \mathrm{v})$ solution, before centrifugation for additional $10 \mathrm{~min}$, followed by refrigeration for $24 \mathrm{~h}$ in glacial acetic acid and methanol solution. Cells suspended in the fixative solution were dropped onto cold and clean slides and allowed to dry at room temperature. After $24 \mathrm{~h}, 5 \mathrm{~N} \mathrm{HCl}$ was added to the slides for $30 \mathrm{~min}$. Distilled water was used for the washes. When totally dry, the slides were stained with Schiff's reagent for 90 min and counterstained with $0.5 \%$ FastGreen for $3 \mathrm{~min}$. One thousand cells were analyzed using an optical microscope and the number of pyknotic cells (PYC), karyolitic cells (KYL), karyorrhetic cells (KHC), condensed chromatin (CC), binucleated cells $(\mathrm{BN})$, basal cells $(\mathrm{BC})$, and differentiated cells (DIFF) were counted. Additional 2.000 cells, in two slides, were analyzed to count micronucleated cells (MNi) and nuclear buds. The images were captured on the $40 \mathrm{X}$ objective, in an Olympus Bx60 ${ }^{\circledR}$ photomicroscope coupled to an Olympus DP71 camera, with the aid of the DP Controler 3.2.1 program 276.

Statistical analysis. Statistical analysis of the data was performed using a paired $t$-test, comparing the exposed group to the control group and considering a confidence interval at $95 \%$.

\section{Results}

According to the demographic characteristics of the population no statistically significant differences were observed between the exposed and control groups (Table I), suggesting that paired statistical tests can be used. Furthermore, no significant 


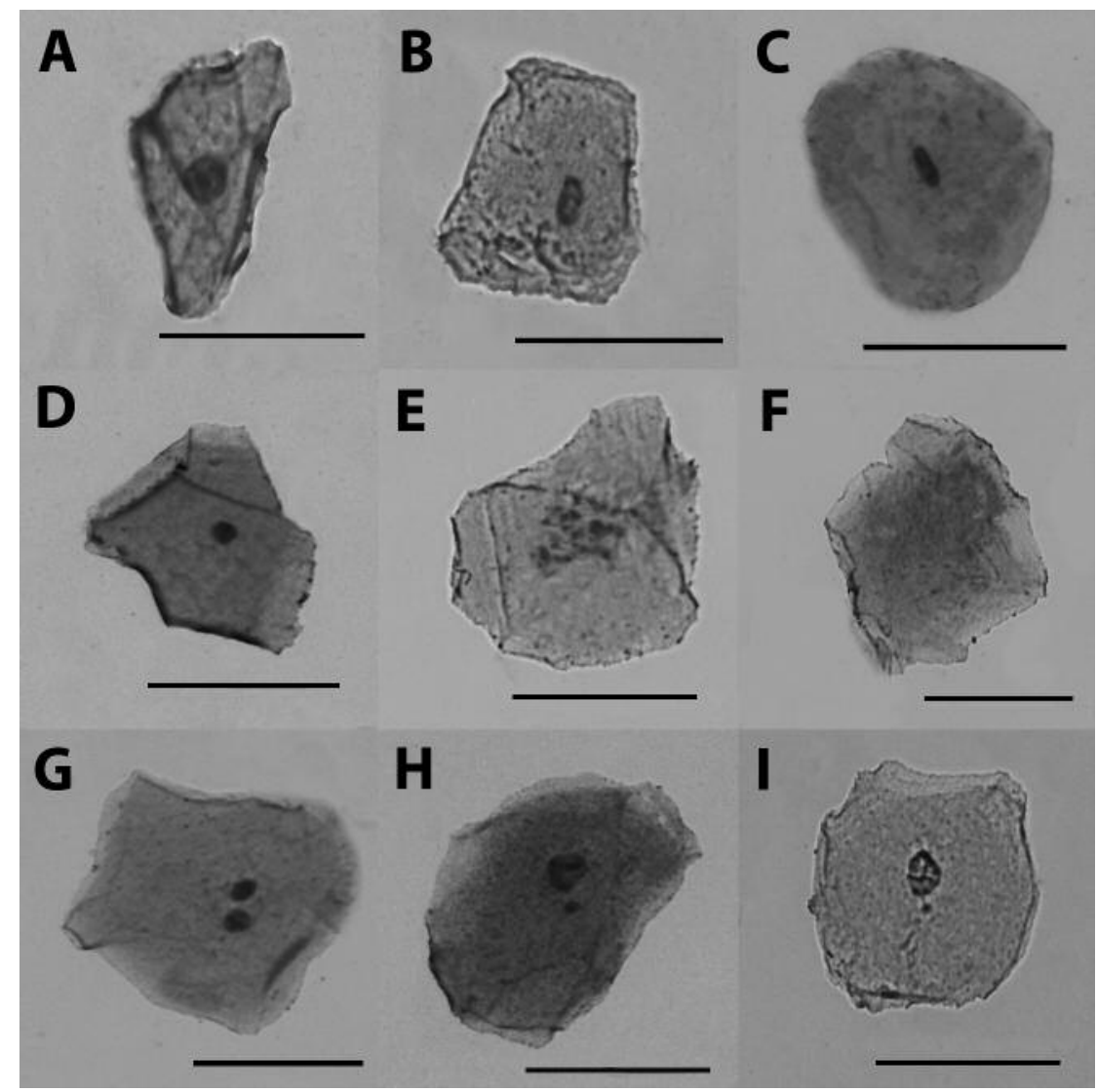

Figure 1. Main cell types observed. (A) Basal cell. (B) Differentiated cell. (C) Condensed chromatin cell. (D) Pyknotic cell. (E) Karyorrhetic cell. (F) Karyolitic cell. (G) Binucleated cells. (H) Micronucleated cell. (I) Cell with nuclear bud.

association of the BMCyt results with age, gender and alcohol consumption as confounding variables in the analysis were observed, arguing that our results can be extrapolated due to occupational exposure.

After evaluation of the structural profiling of buccal cells, an increase in all parameters, but DIFF, was observed in the exposed group $(p<0.05$; Table II). DIFF cells were decreased $(p<0.001)$ in the exposed group compared to the control group (Table II). In summary, all parameters were statistically different in the exposed group compared to the control group, suggesting an extensive DNA damage and cellular changes due to occupational exposure as a car painter. Figure 1 presents some abnormalities evaluated in our study.

\section{Discussion}

The goal of our study was to profile car painters using the BMCyt test and evaluate cellular biomarkers for DNA damage, genomic (in)stability and cellular kinetics. The first two parameters analysed were BC and DIFF since both reflect the proliferative activity of buccal cells (1) and their alteration could argue for possible alterations in other parameters. Indeed, an increase in $\mathrm{BC}$ and a decrease in DIFF were the first evidence of cell cycle abnormalities observed in the exposed group ( $p<0.001$; Table II) compared to the non-exposed group. Additionally, BN frequencies were significantly increased in the exposed group, another evidence of defects in cytokinesis (1). Silva et al. (19) have pointed out that increased frequencies of $\mathrm{BN}$ cells favor the appearance of DNA damage.

As follows, according to cell death (necrosis and apoptosis) parameters, the number of PYK, CC, KYL and $\mathrm{KHC}$ was significantly increased in the exposed group ( $p<0.05$; Table II) compared to the control group. These parameters can be regarded as a response to cytotoxic compounds (20). Apoptosis induction is associated to significant DNA damage (21) and increased rates of cellular proliferation and apoptosis are observed in early stages of tumorigenesis (22). As expected, we observed a statistically significant increase in the frequencies of $\mathrm{MNi}$ and NBuds $(p<0.001$; Table II), two parameters of DNA damage and genome instability. NBuds represent nuclear mutations (20) 
and a statistically increase in Nbuds and/or other nuclear abnormalities in oral cavity cells are associated with genotoxic and mutagenic exposure (23). Overall, our results pointed out to an extensive DNA damage and genome instability and alterations in cellular kinetics in the buccal cells of car painters occupationally exposed.

Particularly, Moro et al. (24) observed an increase in oxidative damage in car painters. Recently, Hoyos-Giraldo et al. (16) observed an association between years of occupational exposure as a painter and organic solvents levels in urothelial cells. As a matter of fact, some studies have already shown a positive association between car painting and DNA damage $(25,26)$, but as far as we know, our study is the first to evaluate the occupational exposure of car painters using a multimarker test as BMCyt, unravelling not only the DNA damage status, but also potential cellular phenotypes associated with genome instability and alterations in the cellular kinetics as early biomarkers for future disease and cancer risk.

Interestingly, Chang et al. (27) have observed that painters wearing protective masks were significantly less exposed to inhalation of xylene and ethyl benzene, but not to dermal absorption. In our study, $90 \%$ of the workers declared no use of any personal protective equipment. Furthermore, they declared that their work environment had no basic collective protective equipments or proper ventilation, which increases not only their exposure but also indirectly the exposure of others in the same environment, independently of their job. Thus, we can predict that our exposed group was exposed to different substances during a workday, even if they were not directly manipulating specific chemical mixtures.

Finally, it is disturbing to know that literature is full of reports associating painting with cancer, especially considering that $>90 \%$ of all human cancers are of epithelial origin $(16,17,28)$. Recently, Jung et al. (28) observed that Canadian painters occupationally exposed had high risk of lung cancer, corroborating the IARC classification.

Overall, we observed statistically significant differences in all parameters in our exposed group $(p<0.05)$, summarized in accelerated cell proliferation, defects in cytokinesis, and increase in DNA damage and genome instability. Our study evaluated only cytologic markers, but all parameters could be used as early biomarkers for future disease risk assesement. Furthermore, the use of individual protective equipments is essential to prevent the increased risk, but most of the individuals in our study declared no use. Given the clear association with cancer, relative information should be provided for these individuals, and public policies should be updated, ranging from regular inspections, limited time of exposure and ideal work conditions, in order to guarantee a better quality of life and reduced risk.

\section{Conflicts of Interest}

The Authors declare that there is no conflict of interest regarding this study.

\section{Authors' Contributions}

APRF collected the sample, performed most of the methods and contributed on data analysis; MADS contributed to conceive the presented hypothesis, data analysis and wrote the manuscript; NRD collected the sample and contributed on methods and data analysis; LPGD conceived the presented hypothesis, supervised APRF and NRD on all procedures and wrote/corrected the manuscript. All Authors discussed the results and contributed to the final manuscript.

\section{Acknowledgements}

This work was supported by Fundacao Araucaria (Parana).

\section{References}

1 Thomas P, Holland N, Bolognesi C, Kirsch-Volders M, Bonassi S, Zeiger E, Knasmueller S and Fenech M: Buccal micronucleus cytome assay. Nat Protoc 4: 825-837, 2009. PMID: 19444240. DOI: $10.1038 /$ nprot.2009.53

2 Khan AW, Nersesyan A, Knasmüller S, Moshammer H and Kundi M: Nuclear anomalies in exfoliated buccal cells in Pakistani cotton weavers. Mutagenesis 30: 613-619, 2015. PMID: 25805022. DOI: 10.1093/mutage/gev022

3 Silveira MAD, Kazanovski M, Ribeiro DL, Cechinato CN and d Arce LPG: Formaldehyde exposure in medical students: a short period of contact causes DNA damage and instability. Int J Multispeciality Health 2: 1-7, 2016.

4 Filho AP, Silveira MAD, do Nascimento CB and d Arce LPG: Integrative study of cell damage and cancer risk in gas station attendants. Int J Environ Health Res 28: 1-7, 2017. PMID: 29232963. DOI: 10.1080/09603123.2017.1415305

5 de Oliveira Galvão MF, de Queiroz JDF, Duarte EDSF, Hoelzemann JJ, de André PA, Saldiva PHN, Menezes Filho JA and Batistuzzo de Medeiros SR: Characterization of the particulate matter and relationship between buccal micronucleus and urinary 1-hydroxypyrene levels among cashew nut roasting workers. Environ Pollut 220: 659-671, 2017. PMID: 27839996. DOI: $10.1016 /$ j.envpol.2016.10.024

6 Gashi G, Mahovlić V, Manxhuka-Kerliu S, Podrimaj-Bytygi A, Gashi L and Elezaj IR: The association between micronucleus, nucleoplasmic bridges, and nuclear buds frequency and the degree of uterine cervical lesions. Biomarkers 23: 364-372, 2018. PMID: 29338484. DOI: 10.1080/1354750X.2018.1428828

7 Da Silva VHP, Andrade MC, Claudio SR, Yujra VQ, Alpire MES, Dos Santos JN, Cury PR and Ribeiro DA: Genomic instability in buccal mucosal cells of municipal street sweepers as evaluated by micronucleus test. Anticancer Res 38: 31233126, 2018. PMID: 29715151. DOI: 10.21873/anticanres. 12573

8 Silveira MAD, Antonelli AS, Fiorelli BO and D'arce LPG: Cytological multimarker screening using BMCyt test in waterpipe smokers: an integrative study of cell damage, toxicological and cancer risk. J Genetics 97: 399-404, 2018. PMID: 29932059. DOI: 10.1007/s12041-018-0923-y 
9 Claudio SR, Simas JMM, Souza ACF, Do Carmo Baracho de Alencar M, Yamauchi LY and Ribeiro DA: Genomic Instability and citotoxicity in buccal mucosal cells of workers in banana farming evaluated by micronucleus test. Anticancer Res 39: 1283-1286, 2019. PMID: 30842159. DOI: 10.21873/anticanres. 13239

10 Souza AC, da Silva VH, Seixas C, de Olveira Scudeller TT, do Amaral MT, Ribeiro DA: Cytogenetic biomonitoring in Buccal mucosa cells from women submitted to chemotherapy after mastectomy for breast cancer. Anticancer Res 36: 1955-1958, 2016. PMID: 27069186.

11 Leon-Mejia G, Luna-Rodriguez I, Trindade C, Oliveros-Ortíz L, Anaya-Romero M, Luna-Carrascal J, Navarro-Ojeda N, RuizBenitez M, Franco-Valencia K, Da Silva J, Henriques JAP, Muñoz-Acevedo A and Quintana-Sosa M: Cytotoxic and genotoxic effects in mechanics occupationally exposed to diesel engine exhaust. Ecotoxicol Environ Saf 171: 264-273, 2019. PMID: 30612014. DOI: 10.1016/j.ecoenv.2018.12.067

12 Martino-Roth M, Vie'gas J, Amaral M, Oliveira L, Ferreira FLS and Erdtmann B: Evaluation of genotoxicity through micronuclei test in workers of car and battery repair garages. Genet Mol Biol 25: 495-500, 2002. DOI: 10.1590/S1415-47572002000400021

13 Ahmad I, Khan B, Khan S, Khan MT and Schwab AP: Assessment of lead exposure amoung automobile technicians in Khyber Pakhtunkhwa, Pakistan. Sci Total Environ 15: 293-299, 2018. PMID: 29574373. DOI: 10.1016/j.scitotenv.2018.03.160

14 International Agency for Research on Cancer (IARC): Working Group on the Evaluation of Carcinogenic Risks to Humans. In: Chemical agents and related occupations, IARC monographs on the evaluation of carcinogenic risks to humans 100: 9, 2012. PMID: 23189753.

15 International Agency for Research on Cancer (IARC): Painting, firefighting, and shiftwork. In: International Agency for Research on Cancer, editor, Monographs on the Evaluation of the Carcinogenic Risks to Humans 98: 9-764, 2010. PMID: 21381544

16 Hoyos-Giraldo LS, Escobar-Hoyos LF, Saavedra-Trujillo D, Reyes-Carvajal I, Muñoz A, Londoño-Velasco E, Tello A, CajasSalazar N, Ruíz M, Carvajal S and Santella RM: Gene-specific promoter methylation is associated with micronuclei frequency in urothelial cells from individuals exposed to organic solvents and paints. J Expo Sci Environ Epidemiol 26: 257, 2016. PMID: 25993025. DOI: $10.1038 /$ jes.2015.28

17 Villalba-Campos M, Chuaire-Noack L, Sánchez-Corredor MC and Rodon-Lagos M: High chromosomal instability in workers occupationally exposed to solvents and paint removers. Mol Cytogenet 9: 46, 2016. PMID: 27325915.

18 CDC - Centers for Disease Control: Cigarette smoking among adults - United States. Morbity and mortality weekly report 51: 642-645, 2000.

19 Silva AE, Rados PV, Da Silva-Lauxen I, Gedoz L, Villarinho EA and Fontanella A: Nuclear changes in tongue epithelial cells following panoramic radiography. Mutat Res Genet Toxicol Environ Mutagen 632: 121-125, 2007. DOI: 10.1016/ j.mrgentox.2007.05.003
20 Bolognesi C, Knasmueller S, Nersesyan A, Thomas P and Fenech M: The HUMNxl scoring criteria for different cell types and nuclear anomalies in the buccal micronucleus cytome assay - an update and expanded photogallery. Mutat Res 753: 100-113, 2015. PMID: 23942275. DOI: 10.1016/j.mrrev.2013.07.002

21 Fenech M: Cytokinesis-block micronucleus cytome assay. Nat Protoc 2: 1084, 2007. PMID: 17546000. DOI: 10.1038/nprot. 2007.77

22 Derka S, Vairaktaris E, Papakosta V, Vassiliou S, Acil Y, Vylliotis A, Spyridonidou S, Lazaris AC, Mourouzis C, Kokkori A, Moulavasili P, Perrea D, Donta I, Yapijakis C and Patsouris E: Cell proliferation and apoptosis culminate in early stages of oral oncogenesis. Oral Oncol 42: 540-550, 2006. PMID: 16464633. DOI: 10.1016/j.oraloncology.2005.10.008

23 Arul P: Application of liquid-based cytology preparation in micronucleus assay of exfoliated buccal epithelial cells in road construction workers. Indian J Dent Res 28: 413-417, 2017. PMID: 28836533. DOI: 10.4103/ijdr.IJDR_665_16

24 Moro AM, Brucker N, Charão M, Bulcão R, Freitas F, Baierle M, Nascimento S, Valentini J, Cassini C, Salvador M, Linden R, Thiesen F, Buffon A, Moresco R and Garcia SC: Evaluation of genotoxicity and oxidative damage in painters exposed to low levels of toluene. Mutat Res 746: 42-48, 2012. PMID: 22405974. DOI: 10.1016/j.mrgentox.2012.02.007

25 Gajalakshmi P, Balasundaram A, Venkatesan P, Santhiya ST and Ramesh A: Cytogenetic studies on spray painters in south India. Mutat Res 514: 1-6, 2007. PMID: 11815239. DOI: 10.1016/ s1383-5718(01)00316-3.

26 Pereira da Silva VH, Gomes de Moura CF, Spadari-Bratfisch RC and Araki Ribeiro D: Cytogenetic biomonitoring of peripheral blood and oral mucosa cells from car painters. Toxicol Mech Methods 22: 497-501, 2012. PMID: 22482703. DOI: 10.3109/ 15376516.2012.680621

27 Chang FK, Chen ML, Cheng SF, Shih TS and Mao IF: Evaluation of dermal absorption and protective effectiveness of respirators for xylene in spray painters. Int Arch Occup Environ Health 81: 145-150, 2007. PMID: 17492305. DOI: 10.1007/ s00420-007-0197-9

28 Jung JKG, Feinstein SG, Lazgare LP, Macleod JS, Arrandale VH, McLeod CB, Peter A and Demers PA: Examining lung cancer risks across different industries and occupations in Ontario, Canada: the establishment of the Occupational Disease Surveillance System. Occup Environ Med 75: 545-552, 2018. DOI: 10.1136/oemed-2017-104926
Received July 19, 2019

Revised August 3, 2019

Accepted August 5, 2019 